Jelena Peković ${ }^{1}$

Goran Pavlović ${ }^{2}$

Stefan Zdravković ${ }^{3}$

Ekonomski fakultet, Univerzitet u Kragujevcu
SCIENTIFIC REVIEW ARTICLE doi: 10.5937/ekonomika2002103P

Received: February, 13. 2020.

Accepted: April, 14. 2020.

\title{
THE INFLUENCE OF INTELLECTUAL CAPITAL ON FINANCIAL PERFORMANCE OF COMMERCIAL BANKS IN THE REPUBLIC OF SERBIA ${ }^{4}$
}

\begin{abstract}
Successful banks are those that are constantly innovating, relying on new technologies and focusing on the skills of their employees. Intellectual capital, as a form of intangible assets, is a key success factor for commercial banks. Therefore, the subject of this research is the impact of intellectual capital components on the financial performance of commercial banks in the Republic of Serbia. The results showed a positive statistically significant impact of intellectual capital on the ROA. Additionally, the components of intellectual capital related to human and relational capital had a statistically significant impact on the ROE, while structural capital did not.
\end{abstract}

Key words: intellectual capital, commercial banks, financial performance, VAIC, $R O A, R O E$

JEL classification: 034

\section{УТИЦАЈ ИНТЕЛЕКТУАЛНОГ КАПИТАЛА НА ФИНАНСИЈСКЕ ПЕРФОРМАНСЕ КОМЕРЦИЈАЛНИХ БАНАКА У РЕПУБЛИЦИ СРБИЈИ}

\begin{abstract}
Апстракт
Успешне банке су оне које непрестано врше иновачије, осланају се на нове технологије и акиенат стављају на вештине и знања својих запослених. Другим речима, интелектуални капитал, као облик нематеријалне имовине, представља кључни фактор успеха комериијалних банака. Стога, предмет истраживања рада представља утииај компоненти интелектуалног капитала на финансијске перформансе комеричјалних банака у Републици Србији. Резултати анализе показали су позитиван статистички значајан утицај интелектуалног капитала на стопу приноса на укупно уложену имовину. С друге стране, компоненте интелектуалног капитала које се односе на људски и релациони капитал

\footnotetext{
1 jelenapekipekovic@gmail.com, ORCID ID 0000-0002-7528-8286

2 pavlovic.g90@gmail.com, ORCID ID 0000-0002-5557-9262

${ }^{3}$ szdravkovic034@yahoo.com, ORCID ID 0000-0002-0047-3356

${ }^{4}$ This work is part of the Basic Research Project (No. 179062), funded by the Ministry of Education, Science and Technological Development of the Republic of Serbia.
} 
су оствариле статистички значајан утищај,на стопу приноса на укупно уложени капитал, док структурни капитал није.

Кључне речи: интелектуални капитал, комериијалне банке, финансијске перфомансе, ВАИЦ, РОА, РОЕ

\section{Introduction}

The most challenging dimension in knowledge management is the recognition of knowledge as another (or most important) performance factor. This is without a doubt a opposition of the generally accepted materialistic opinion that favors exclusively modern technics and technology. Intellectual potential (knowledge) can be regarded as a tacit and explicit phenomenon (Mavridis, 2005). As such, intellectual capital is particularly characteristic of the banking sector. Namely, in the banking sector there is reliable data in the form of published financial reports, the business nature of the banking sector is "intellectually intensive" and all staff are more intellectually homogeneous than in other sectors of the economy (Kubo \& Saka, 2002). Therefore, the aim of the paper is to determine whether intellectual capital, measured by the VAIC coefficient, has a positive impact on financial performance in the Serbian banking sector, as measured by indicators - return on total invested capital of banks (ROE) and rates of return on total invested assets (ROA). The applied qualitative methodology in the paper first highlighted the key theoretical aspects of intellectual capital in the banking sector, and then the impact of intellectual capital on the financial performance of banks in the Republic of Serbia was examined with the appropriate quantitative methodology.

\section{Literature review}

The term intellectual capital is differently defined by different researchers. Generally, the term intellectual capital is used to refer to the intangible assets of a company that have significant impact on business, performance and overall business success (Aruppala et al., 2015). Synonym for intellectual capital is often "invisible" or "intangible" assets, and therefore can be understood as a set of knowledge and skills of employees, patents, processes, technology, organizational culture, brand, consumer relations, business partners and other stakeholders (Janosevic et al., 2013). Thus, intellectual capital represents all those factors that can enable a company to gain competitive advantage. In order to fully understand the nature of intellectual capital, its constituent elements must be identified. The most commonly used classification divides intellectual capital into three categories: human, structural and relational capital (Bontis, 1998). Intellectual capital in the banking sector is very important, as banks rely heavily on human and relational capital in their work. Therefore, the banking sector can be characterized as an industry based on knowledge and skills and customer relationships (Muhammad \& Ismail, 2009). In conducting business operations, banks rely on the knowledge and expertise of employees, creating good customer relationships and using information and 
communication technology. Although the physical, that is material capital of the bank is very important in this case, intangible assets, ie intellectual capital, play a crucial role in creating quality service, and thus in creating good business and financial results (Lipunga, 2015). This is confirmed by some of the results of numerous studies conducted worldwide, which are presented in this paper. When it comes to similar research in the Republic of Serbia, to the authors' knowledge, there are few papers examining the relationship between intellectual capital and financial performance of commercial banks, which is the main motive for writing this paper. A study conducted by Radic (2018) on the example of Serbian banks shows that when ROA is selected as a measure of profitability, the level of bank indebtedness determines the degree of influence of intellectual capital on the stated rate of return on assets, so that at higher level of indebtedness, the impact of intellectual capital on bank profitability is negative. In addition, the study showed the negative impact of intellectual capital on the rate of return on bank invested capital (ROE). Bontis et al (2013) found that different components of intellectual capital affects different financial performance. Thus, the authors concluded that human capital affects employee productivity, structural affects ROE, and relational capital affects ROE.

As a central component of intellectual capital, human capital (HCE) contains the knowledge, skills, experience, and capabilities of members of an organization (Slavkovic \& Simic, 2019; Roslender \& Fincham, 2004). Individual knowledge, expertise and skills of the employees are most important resources and a source of sustainable competitive advantage (Collins \& Clark, 2003; Lado \& Wilson, 1994). Knowledge in the banking industry is a more significant component of business than in most other sectors, as banking operations are highly regulated, diversified, sensitive and risky for the economy and society (Mention, 2013). In the banking sector, much of the added value is created in direct interaction between the client and the bank's employees, and the quality of the value depends on the emotional intelligence, creativity and knowledge of the employee. The results of various studies have shown a significant impact of human capital on banks' financial performance (Saengchan, 2007; Bontis, 1998; Carbita \& Bontis 2008). Based on the above, the following research hypotheses can be formulated:

\section{H1: Banks with higher HCE achieve higher ROA. \\ H2: Banks with higher HCE achieve higher ROE.}

Unlike human capital, structural capital (SCE) is company-owned and comprises information systems and databases, routines, procedures, processes that reflect business, as well as creativity and innovation and corporate culture. Because services require a significant amount of human activity, they rarely adhere to systematic and standardized processes. The above suggests that parts of structural capital, such as procedures, are less relevant to services than they are in the manufacturing process (Kianto et al., 2010). The opposite is true for information and communication technologies, especially in the banking sector, where business operations are highly dependent on the same. As such, structural capital is a component of intellectual capital that positively affects banks' financial performance (Bontis et al., 2013; Carbita \& Bontis, 2008). Based on the above, the following research hypotheses can be formulated:

\section{H3: Banks with higher SCE score higher ROA. H4: Banks with higher SCE score higher ROE.}


Relational capital (CEE) refers to the ability of a company to interact with external stakeholders such as customers, suppliers, competitors, trade and industry associations, as well as the knowledge embedded in these relationships (Edvinsson \& Malone 1997; Bontis, 1998). In the banking industry, professional associations play a prominent role, acting as a provider of information, a catalyst for networking activities, and a lobbyist for national entities. Reputation, which reflects the image of a company, is also an integral component of relational capital. Those companies that have a better reputation are able to attract more consumers, achieve higher levels of sales, build consumer loyalty and commitment, and so on (Mention, 2013). Building good customer relationships is crucial for the banking sector, as a satisfied customer regularly uses the services of the bank, demonstrates loyalty and communicates their satisfaction to others. In this case, there is a positive effect of relational capital on the financial performance of banks (Cabrita \& Vaz, 2006). Based on the above, the following research hypotheses can be formulated:

\section{H5: Banks with higher CEE score higher ROA. H6: Banks with higher CEE score higher ROE}

\section{Research methodology}

The data collected for this research comes from the official reports of commercial banks operating in Serbia in the period 2015-2017. The sample consists of a total of 89 banks, of which 29 represent banks operating in the Republic of Serbia during 2017 and 30 banks each operating in 2016 and 2015, which is the total number of banks in the territory of the Republic of Serbia in given years. The main source of information was the Serbian Business Registers Agenncy.

Intellectual capital is this research is measured by VAIC coefficient (Value Added Intellectual Coefficient). The guiding principle of this model is to determine the contribution of all company resources (human, structural and physical) to value creation (VA), which is obtained as follows (Pulić, 2004):

$$
\mathrm{VA}=\mathrm{OUT}-\mathrm{IN}
$$

Output (OUT) represent the total sales realized in the market, and the inputs (IN) cover all the costs of managing a bank, with the exception of human resource related costs, which are seen as an investment, not an expense (Janosevic et al., 2013). The next step is to calculate Human Capital Efficiency (HCE), which is obtained as follows:

$$
\mathrm{HCE}=\mathrm{VA} / \mathrm{HC}
$$

$\mathrm{HC}$ in the given formula refers to the amount of earnings of employees during one fiscal year. The next component of intellectual capital is structural capital. Structural Capital Efficiency (SCE) is calculated as follows:

$$
\mathrm{SCE}=\mathrm{SC} / \mathrm{VA}
$$

Intelectual Capital Efficiency (ICE) is obtained as the sum of HCE and SCE:

$$
\mathrm{ICE}=\mathrm{HCE}+\mathrm{SCE}
$$


Finnaly, Capital Employed Efficiency (CEE), is derived from the relationship between value added and net assets of the company:

$$
\mathrm{CEE}=\mathrm{VA} / \mathrm{CE}
$$

Capital Employed (CE) is already invested capital in the business and it represents the net assets of the company. In order to ensure the comparability of the overall value creation of the banks, the two indicators mentioned above must be combined:

$$
\mathrm{VAIC}=\mathrm{ICE}+\mathrm{CEE}
$$

The data collected were processed in the statistical package SPSS V23. Descriptive statistical analysis, normal distribution test for non-parametric data, correlation and multiple regression analysis were used from statistical methods.

\section{Research results}

When presenting the characteristic values in the descriptive statistical analysis, the starting point is the data for all 89 commercial banks that operated in the period from 2015 to 2017 in the Republic of Serbia. Table 1 shows the results of descriptive statistical analysis for two dependent variables: ROA and ROE and for four independent variables: HCE, SCE, CEE and VAIC.

Table 1: Results of descriptive statistical analysis

\begin{tabular}{|c|c|c|c|c|}
\hline & Min & Max & Mean & Standard deviation \\
\hline ROA & $-0,08$ & 0,1205 & 0,0208 & 0,0383 \\
\hline ROE & $-0,176$ & 0,9923 & 0,1057 & 0,2323 \\
\hline HCE & $-0,9975$ & 11,93 & 2,62 & 3,11 \\
\hline SCE & $-6,02$ & 2,060 & 0,074 & 1,84 \\
\hline CEE & $-0,29$ & 0,059 & 0,1683 & 0,0187 \\
\hline VAIC & $-5,86$ & 13,1 & 2,86 & 4,10 \\
\hline
\end{tabular}

Sorce: Authors

By looking at the results of descriptive statistics, it can be seen that the highest value, and also the highest arithmetic mean, is achieved by human capital efficiency (HCE), which leads to the conclusion that human capital is the whitest component of the intellectual capital of the banking sector in the Republic of Serbia. In order to determine whether a normal data distribution was represented in a given sample, a test of normal data distribution was conducted. Given that the sample is less than or equal to 30 when viewed individually each year, Kolmogorov-Smirnov and Shapiro-Wilk tests of normal data distribution were applied. The tests were performed individually for each year, and Table 2 shows the summary data for all 89 banks in the sample. 
Table 2: Test results of normal data distribution

\begin{tabular}{|c|c|c|c|c|c|c|}
\hline & \multicolumn{3}{|c|}{ Kolmogorov-Smirnov } & \multicolumn{3}{c|}{ Shapiro-Wilk } \\
\cline { 2 - 7 } & Statistics & df & sig. & Statistics & df & sig. \\
\hline ROA & 0,207 & 89 & 0,000 & 0,881 & 89 & 0,000 \\
\hline ROE & 0,161 & 89 & 0,000 & 0,853 & 89 & 0,000 \\
\hline HCE & 0,214 & 89 & 0,000 & 0,767 & 89 & 0,000 \\
\hline SCE & 0,343 & 89 & 0,000 & 0,57 & 89 & 0,000 \\
\hline CEE & 0,144 & 89 & 0,161 & 0,945 & 89 & 0,163 \\
\hline VAIC & 0,193 & 89 & 0,000 & 0,875 & 89 & 0,000 \\
\hline
\end{tabular}

Source: Authors

Results in the previous table shows that the only variable with a normal distribution is the one related to the efficiency of relational capital. Since there is only one variable (CEE) with normal data distribution, Spearman correlation analysis should be applied as a next step.

Table 3: Results of correlation analysis

\begin{tabular}{|c|c|c|c|c|}
\hline \multicolumn{2}{|c|}{} & HCE & SCE & CEE \\
\hline \multirow{2}{*}{ ROA } & Correlation coefficient & $0,699 * *$ & $0,522^{* *}$ & $0,860 * *$ \\
\cline { 2 - 5 } & sig. & 0,001 & 0,003 & 0,000 \\
\hline \multirow{2}{*}{ ROE } & Correlation coefficient & $0,689 * *$ & 0,203 & $0,751 * *$ \\
\cline { 2 - 5 } & sig. & 0,002 & 0,310 & 0,000 \\
\hline
\end{tabular}

\section{Source: Authors}

Note: **- The correlation coefficients are significant at the level 0,01

By looking at the results of the correlation analysis in Table 3, it can be concluded that the values of the Spirman coefficient are statistically significant at the 0.01 level for the HCE, SCE and CEE components, while on the other hand only the SCE component does not have a statistically significant correlation with the ROE. The highest degree of correlation was observed in the case of ROA and CEE (0.860). In order to test the research hypotheses, ie to examine the impact of intellectual capital components on ROA, a multiple regression analysis was applied and the results of which are presented in the Table 4.

Table 4: Results of multiple regression analysis (dependent variable: ROA)

\begin{tabular}{|c|c|c|c|}
\hline & B & sig. & VIF \\
\hline HCE & $0.385^{* *}$ & 0,008 & 1,442 \\
\hline SCE & $0.188^{*}$ & 0,041 & 1,073 \\
\hline $\mathrm{CEE}$ & $0.689^{* *}$ & 0,000 & 1,387 \\
\hline
\end{tabular}

Source: Authors

Note: Level of significance of coefficients: $* * 0,01 ; * 0,05 ; R^{2}=0,856$

The coefficient of determination $\left(\mathrm{R}^{2}\right)$ is 0,856 , which means that $85,6 \%$ of the variability of the rate of return on the total invested assets (ROA) is explained by the 
given regression model. Results shows that all three components of VAIC-a: HCE, SCE and CEE have a statistically significant effect on ROA. The biggest impact is the CEE component where the beta coefficient $(\beta)$ is 0.689 . A variance inflation factor (VIF) is used as a test to examine multicollinearity problems. According to Field (2000), the VIF value must be below 5 for the statistical model to be relevant. In this case, the coefficient values for all three components are less than 5 , indicating the absence of multicollinearity in the model. Based on the results of the regression analysis, it can be concluded that the H1, H3 and H5 hypotheses were confirmed. Table 5 presents the results of a multiple regression analysis, which measures the impact of intellectual capital components on the rate of return on the total invested capital of a bank (ROE).

Table 5: Results of multiple regression analysis (dependent variable: ROE)

\begin{tabular}{|c|c|c|c|}
\hline & B & sig. & VIF \\
\hline HCE & $0.364^{* *}$ & 0,009 & 1,442 \\
\hline SCE & 0,006 & 0,959 & 1,073 \\
\hline CEE & $0,536^{* *}$ & 0,001 & 1,387 \\
\hline
\end{tabular}

Source: Authors

Note: Level of significance of coefficients: $* * 0,01 ; R^{2}=0,683$

The coefficient of determination $\left(\mathrm{R}^{2}\right)$ is 0,683 , which means that $68,3 \%$ of the the variability of the rate of return on total invested capital (ROE) is explained by the given regression model. The results show that VAIC components: HCE and CEE have a statistically significant effect on ROE. The CEE component has a greater impact where the beta coefficient $(\beta)$ is 0.536 . The SCE component does not have a statistically significant effect on the ROE, and in addition a very low beta coefficient value was achieved in this case. When it comes to the problem of multicollinearity, the VIF factor is less than 5, as in the previous case, indicating the absence of the problem of multicollinearity. Based on the results of the regression analysis, it can be concluded that the $\mathrm{H} 2$ and $\mathrm{H} 6$ hypotheses were confirmed, while the H4 hypothesis was not confirmed.

\section{Conclusion}

The results of the in this paper showed a high degree of correlation between the $\mathrm{HCE}$ and CEE components and in the case of ROA and ROE, while the SCE component correlated only with ROA. Multiple regression analysis that included two models was used to test the hypotheses. The first model aimed to analyze the impact of HCE, SCE, and CEE on ROA and the second on ROE. The first regression model showed a statistically significant influence of all three components of VAIC on ROA, with the first, third and fifth hypotheses of this study being confirmed, which is consistent with the results of previous research (Radić, 2018). The second regression model showed statistically significant influence of HCE and CEE on ROE, while the influence of SCE was not significant. This confirmed the second and sixth hypotheses, while the fourth hypothesis was not confirmed. In a previous study (Bontis et al., 2013) in the case of the impact of $\mathrm{HCE}, \mathrm{SCE}$ and $\mathrm{CEE}$ on ROE, human capital was the only component with no 
significant effect on this measure, whereas SCE and CEE had impacts. In doing so, this study confirmed previous research in the case of $\mathrm{CEE}$ and refuted the results in the case of HCE and SCE.

The theoretical contribution of the paper is reflected in the expansion of scientific knowledge about the impact of intellectual capital on the financial performance of commercial banks. According to the authors, such research is limited in the territory of the Republic of Serbia, thus creating an adequate basis for further research. The managerial contribution of the work is reflected in the presentation of the obtained results to experts, especially human resource managers in banks, who can achieve good financial performance by building a unique intellectual capital. Despite its contribution, the research conducted for the purposes of this paper has a significant number of limitations, which at the same time provides directions for future research. First of all, the first limitation is the sample. A period of three years may not be relevant for reaching the appropriate conclusions. Namely, analyzing a longer period of time would lead to the problem of inconsistent financial statements, so additional efforts would have to be made to make the information comparable. Easily accessible data can define the choice of methodology used in empirical research as well as the choice of regressors included in the research model. Also, as mentioned in the paper, most of the research on this topic used the VAIC method for calculating intellectual capital, despite its limitations, so that for further research it is necessary to define a more precise methodology for measuring intellectual capital and its impact on the financial performance. It is desirable in future research to compare the results obtained from the impact of intellectual capital on the financial performance of banks operating in the Republic of Serbia with banks operating in other countries that have similar economic conditions.

\section{References}

Aruppala, D., Wickramasinghe, V., \& Mahakalanda, I. (2015). Intellectual capital and financial performance in Sri Lankan Banks. In 6th International Conference on Business \& Information (ICBI - 2015) (pp. 37-49). Sri Lanka: University of Kelaniya.

Bontis, N. (1998). Intellectual capital: an exploratory study that develops measures and models. Management Decision, 36(2), 63-76.

Bontis, N., Janošević., S., \& Dženopoljac, V. (2013). Intellectual capital and corporate performance of Serbian banks. Actual Problems of Economics, 142(4), 287-299.

Cabrita, M. \& Vaz, I. (2006). Intellectual capital and value creation: evidence from the Portuguese banking industry. Journal of Knowledge Management, 4(1), 11-20.

Cabrita, M., \& Bontis, N. (2008). Intellectual capital and business performance in the Portuguese banking industry. International Journal of Technology Management, 43(1-3), 212-237.

Collins, C.J., \& Clark, K.D. (2003). Strategic human resource practices, top management team social networks, and firm performance: the role of human resource in creating organizational competitive advantage. Academy of Management Journal, 46(6), 740751. 
Field, A. (2000). Discovering statistics using SPSS for Windows. Thousand Oaks, Sage Publication.

Janošević, S., Dženopoljac, V., \& Bontis, N. (2013). Intellectual capital and financial performance in Serbia. Knowledge and Process Management, 20(1), 1-11.

Kianto, A., Hurmelinna-Laukkanen, P., \& Ritala, P. (2010). Intellectual capital in service and product-oriented companies. Journal of Intellectual Capital, 11(3), 305-325.

Kubo, I., \& Saka, A. (2002). An inquiry into the motivations of knowledge workers in the Japanese financial industry. Journal of Knowledge Management, 6(3), 262271.

Lado,A.A., \& Wilson, M.C.(1994). Human resource systems and sustained competitive advantage: a competency-based perspective. Academy of Management Review, 19(4), 699-727.

Lipunga, A.M. (2015). Intellectual capital performance of the commercial banking sector of Malawi. International Journal of Business and Management, 10(1), 210-222.

Mavridis, D.G. (2005). Intellectual capital performance determinants and globalization status of Greek listed firms. Journal of Intellectual Capital, 6(1), 127-140.

Mention, A.M. (2013). Intellectual capital and performance within the banking sector of Luxembourg and Belgium. Journal of Intellectual capital, 14(2), 286-309.

Muhammad, N.M.N., \& Ismail, M.K.A. (2009). Intellectual capital efficiency and firm's performance: study on Malaysian financial sectors. International Journal of Economics and Finance, 1(2), 206-212.

Pulić, A. (2004). Intellectual capital-does it create or destroy value? Measuring Business Excellence, 8(1), 62-68.

Radić, S. (2018). The impact of intellectual capital on the profitability of commercial banks in Serbia. Economic Annals, 63(216), 85-109.

Roslender, R., \& Fincham, R. (2004). Intellectual capital accounting in the UK: a field study perspective. Accounting, Auditing and Accountability Journal, 17(2), 178-209.

Saengchan, S. (2007). The role of intellectual capital in creating value in banking industry. Journal of Knowledge Management, 3(2), 15-25.

Slavković, M., \& Simić, M. (2019). Impact of human capital on organizational performance. An empirical study of startup firms in Republic of Serbia. Sustainable Development and Innovation, 147-159. 